\title{
Regulatory factors in the control of muscle development
}

\author{
BY M. J. DAUNCEY AND R. S. GILMOUR \\ Department of Cellular Physiology, The Babraham Institute, Cambridge CB2 4AT
}

\section{Facteurs de régulation dans le contrôle du développement du muscle}

\begin{abstract}
RÉSUMÉ
Les muscles du squelette sont essentiels pour un large spectre de fonctions qui comprennent la respiration, la locomotion, le maintien de la posture et la thermogenèse. Les défaillances dans le développement normal du muscle risquent de compromettre n'importe laquelle de ces fonctions chez le nouveau-né et peuvent aussi avoir des conséquences à long terme sur la santé et le bien-être de l'individu. Cette courte revue porte essentiellement sur les principaux événements de la myogénèse et de la différentiation, et sur leur régulation par (1) des facteurs internes tels que l'innervation, la famille MyoD des facteurs de transcription, les hormones thyroïdiennes et les facteurs de croissance; (2) des facteurs extérieurs tels que la nutrition et la température ambiante. Nous porterons notre attention sur la vie de l'embryon, du foetus et après la naissance chez des mammifères d'espèces différentes, à des stades de maturité différents, et de taille très différente.

Les cellules précurseurs sont d'abord programmées pour former des myoblastes au début du développement de l'embryon; puis intervient leur différenciation en myotubes et leur maturation en myofibres matures. L'activité ATPase des isoformes des chaînes lourdes de la myosine qui s'exprime dans chaque fibre est un facteur clé pour déterminer la capacité contractile, et l'expression séquentielle de des isoformes avant la naissance peut être suivie d'autres transitions entre les isoformes après la naissance. La diversité du myoblaste joue un rôle clé pour déterminer le type de fibre, et les myotubes primaires qui se sont formés au début de la gestation servent de support pour la formation ultérieure des myotubes secondaires. Le nombre des myotypes primaires est un caractère génétique relativement plus fixé que celui des secondaires. Ainsi, la sous-alimentation de la mère et le retard de croissance in utero ont peu d'effet sur le nombres des primaires alors que la formation des secondaires est réduite, aboutissant à un déficit permanent dans les nombres totaux de fibres. Contrairement à ce qui se produit chez les petits mammifères, une génération tertiaire supplémentaire de myotubes se produit dans la fin du développement prénatal et au début du développement post-natal des grands mammifères. Ces tertiaires sont probablement à l'origine d'une proportion substantielle du nombre final des fibres produites, et des résultats préliminaires suggèrent que la nutrition peut affecter leur apparition après la naissance.
\end{abstract}

La famille MyoD et le MEF2 activent la transcription de nombreux gènes spécifiques du muscle à des stades précis de développement. Contrairement à ce qui se produit dans le muscle du foetus et de l'embryon, la famille MyoD peut aussi jouer un rôle d'intermédiaire dans les effets des facteurs externes de l'expression des gènes spécifiques de type des myofibres. Les hormones thyroïdiennes $(\mathrm{TH})$ jouent un rôle clé tout au long du développement et régulent directement les familles des gènes de MyoD et des 
protéines contractiles. Dans le début du développement, la TH agit, par exemple, avec les rétinoïdes et les IGF pour amener les myoblastes à quitter le cycle des cellules et à se différencier en myotubes. Plus tard dans le développement, elles sont impliquées principalement dans l'expression des gènes matures spécifiques du muscle. Il reste à démontrer si elles sont également impliquées dans la différentiation post-natale des myoblastes tertiaires. Le statut énergétique exerce une profonde influence spécifique de muscle sur l'expression des gènes à chaîne lourde de myosine. Un apport faible en énergie aussi bien qu'une demande thermorégulatoire élevée augmentent significativement la proportion de fibres lentes de type I dans les muscles rhomboïdes mais pas dans les longissimus dorsi ni dans les soleus. On suppose que ce modifications peuvent être induites par des modifications concommitantes dans le statut thyroïdien et l'activité contractile, et régulées par des membres de la famille MyoD des protéines.

De nombreux autres aspects du développement du muscle comme la captation du glucose et la résistance à l'insuline pourraient aussi être affectés de façon critique par des facteurs environnementaux. De plus, il est extrêmement probable que des déficits en nutriments spécifiques influencent aussi le développement du muscle, et les interactions gènes-nutriments en relation avec la $\mathrm{TH}$ pourraient être particulièrement significatives. Une meilleure compréhension des mécanismes par lesquels l'environnement dans les premiers temps affectent le développement du muscle a des implications significatives dans l'acquisition de la fonction appropriée du muscle chez tous les jeunes mammifères, et peut aussi avoir des conséquences à long terme dans le domaine de la médecine préventive.

Skeletal muscle is essential for a wide range of functions including breathing, locomotion, maintenance of posture and thermogenesis. Defects in normal muscle development could impair any of these functions in the neonate and this has important implications for the survival and well-being of all mammals. Moreover, inappropriate development of muscle may also have secondary longer-term effects. For example, muscle is an important site of insulin action and abnormalities in its structure and function may affect the ability of insulin to promote glucose uptake. In addition, enhanced energetic efficiency and reduced motor activity could result in an increased risk of obesity and impaired mental development respectively.

Many studies have been undertaken on the regulation of myoblast and myofibre diversity during embryological and early fetal development (Stockdale, 1992). However, the perinatal and early postnatal periods are also critical stages of development during which there are marked changes in nutrition, endocrine status, motor activity and thermal environment, all of which have the potential to exert profound regulatory effects on muscle development at the cellular and molecular levels (Dauncey, 1995a; Symonds et al. 1995).

Fundamental to an understanding of muscle development are the mechanisms which regulate the number, type and size of myofibres. Moreover, essential to normal muscle structure and function is the appropriate development not only of the myofibrillar proteins but also of the mitochondria, respiratory enzymes, sarcolemma, transverse tubules, sarcoplasmic reticulum and associated membrane-bound ATPases. Consideration of all these factors is, however, impossible in the present short review. Attention focuses, therefore, on the main events in myogenesis and differentiation, and their 
regulation during prenatal and postnatal life by (1) intrinsic factors such as innervation, the myogenic determination factor (MyoD) family of transcription factors, thyroid hormones and growth factors and (2) extrinsic factors such as nutrition and environmental temperature.

\section{MYOGENESIS AND DIFFERENTIATION}

In early embryonic development mesenchymal cells differentiate into committed myogenic precursor cells and during fetal development these mononucleated proliferating myoblasts fuse to form elongated multi-nucleate cells or myotubes which do not divide. Synthesis of muscle proteins, and especially the myofibrillar proteins of the sarcomere, eventually results in the displacement of the central nuclei to the cell periphery to form the mature myofibres (Novakofski \& McCusker, 1993). An outline of the main events during myogenesis and differentiation is given in Fig. 1. At least four types of myofibre can be identified within most mature muscles and these vary with respect to their contractile and biochemical properties, which in turn are dependent on the relative expression of several multi-gene families (Gunning \& Hardeman, 1991).

The ATPase activity of the myosin heavy-chain isoforms expressed within each cell plays a central role in determining the contractile ability of each muscle and myofibres are also distinct with respect to their relative proportions of mitochondria and respiratory enzymes, which in turn determine the metabolic properties of the muscle (Pette \&
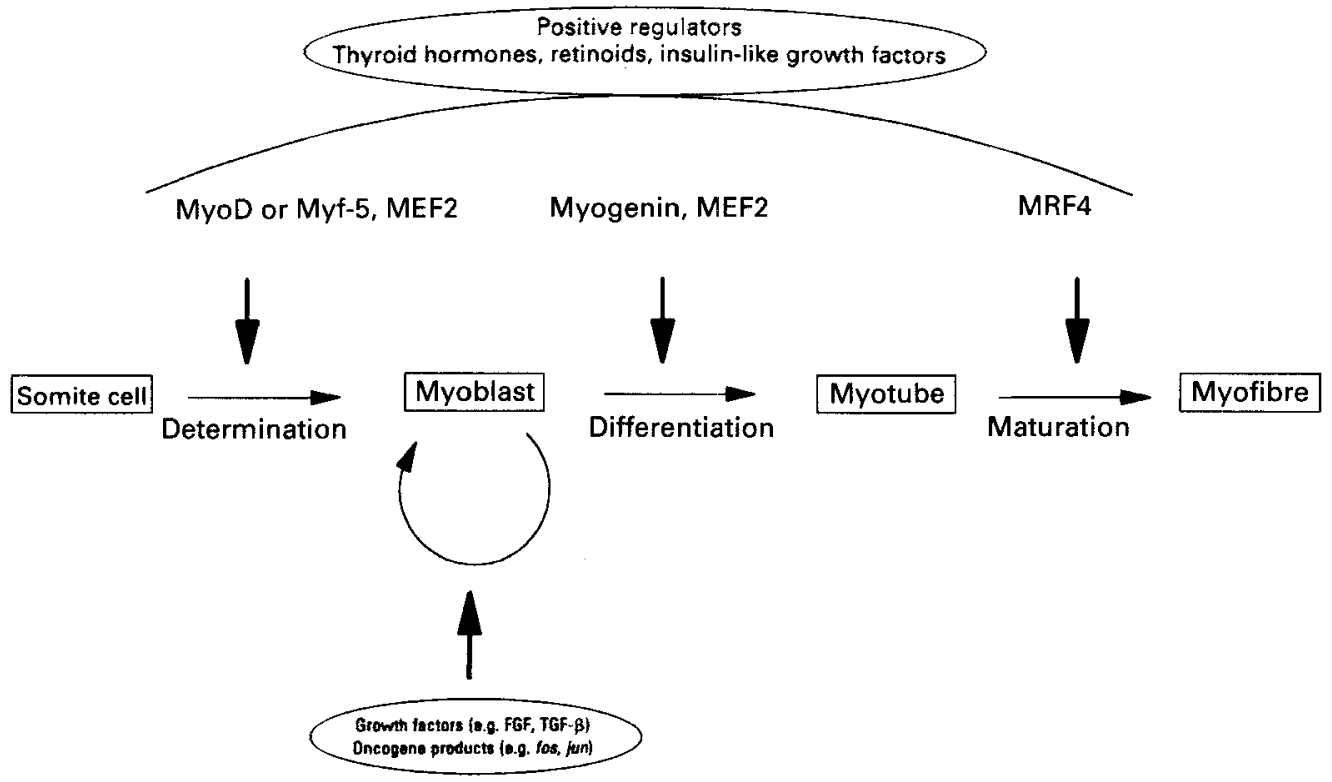

Fig. 1. Outline of main events and regulatory factors involved in myogenesis and differentiation. This simplified diagram highlights some of the points at which specific regulators act (for details, see text). Muscle-specific transcription factors include (a) the myogenic determination factor (MyoD) family which comprises MyoD, Myf-5, myogenin and MRF4, and (b) myocyte-specific enhancer-binding factor 2 (MEF2). Positive regulators act at many stages of development, for example by inducing myoblasts to exit from the cell cycle; many oncogene products and growth factors such as fibroblast growth factor (FGF) and transforming growth factor- $\beta$ (TGF- $\beta$ ) act antagonistically by preventing cell cycle arrest and repressing myogenic gene expression. 
Staron, 1990; Rowlerson, 1994; Chang et al. 1995). Thus, marked differences occur in the myosin heavy-chain isoform and respiratory enzyme contents of, for example, the slow-twitch predominantly oxidative soleus and fast-twitch mixed oxidative and glycolytic longissimus dorsi. During prenatal development myoblast diversity plays a key role in determining fibre type and there are many types of myoblasts in the embryo and fetus each of which is committed to form myotubes with distinct patterns of expression of myosin heavy-chain isoforms (Stockdale, 1992). The sequential expression of these isoforms prenatally (embryonic $\rightarrow$ fetal $=$ neonatal $\rightarrow$ adult ) can be followed by further transitions between adult isoforms (I $\longleftrightarrow$ IIA $\longleftrightarrow$ IIX $\longleftrightarrow$ IIB) postnatally (DeNardi et al. 1993), as a result of changes in contractile activity, hormonal status and nutrition.

The development of muscles in small laboratory animals follows a general pattern. In early embryonic life a small number of primary myotubes form; these extend the full length of the muscle limits and define its shape, origins and insertions. Later in gestation a second generation of myotubes appears, and it is these secondary myotubes that form the main bulk of the muscle. The formation of primary myotubes is independent of innervation, whereas the critical step leading to fusion of myoblasts into secondary myotubes is probably dependent on electrical activity in the mature fibres with which these myoblasts are associated (Ross et al. 1987). Secondary myotubes appear asynchronously over days or weeks and use primary myotubes as a framework which guides their growth towards the tendons. By contrast with small mammals, an additional tertiary generation of myotubes occurs during late fetal and early postnatal development in the muscles of man (Draeger et al. 1987) and other large mammals such as pig (Mascarello et al. 1992) and sheep (Wilson et al. 1992). These tertiary myotubes use secondary myotubes as support and they probably account for a substantial proportion of the final number of fibres produced.

\section{REGULATORY FACTORS}

\section{Muscle-specific transcription factors}

Mechanism of action. Although a detailed account of these regulatory proteins in the embryonic development of muscle is not within the scope of the present review a brief summary may be useful in the context of later discussion. Much attention has focused in recent years on the central role of the MyoD family of transcription factors in regulating muscle development, although more recently it has been established that myocytespecific enhancer-binding factor 2 (MEF2) also plays a major role in myogenesis (Buckingham, 1994).

The MyoD family of nuclear proteins includes MyoD, Myf-5, myogenin and MRF4/ Myf-6/herculin. They belong to a superfamily of basic helix-loop-helix (bHLH) transcription factors and contain a sixty-eight amino acid conserved basic, myc-like, region that is essential for myogenic conversion. The basic region and adjacent HLH motif mediate DNA binding and dimerization respectively. The functions of the MyoD family are probably regulated by interactions with other proteins, and in order to bind their target sequences with high affinity and activate transcription they form heterodimers with ubiquitously expressed members of the bHLH protein family such as E12 and E47, the alternatively spliced products of the E2A gene (Olson, 1993). The heterodimers then bind to a consensus sequence, termed the E-box, found in the promoters or enhancers of many muscle genes. Another group of bHLH proteins, the inhibitor of differentiation 
(Id) family, lack a DNA-binding domain but can also form heterodimers with E12 and E47, preventing them from binding to a MyoD protein and, thus, acting as negative regulators of muscle-specific gene activation (Benezra et al. 1990). Levels of Id protein are repressed during myogenesis. By contrast, when muscle atrophy is induced postnatally by denervation or nerve impulse block, Id transcripts increase 2-7-fold (Gundersen \& Merlie, 1994). Moreover, mice expressing high levels of an Id transgene exhibit fibre atrophy. These findings suggest that the MyoD family and Id work in concert to regulate muscle fibre size and that their biological effects extend to postnatal changes in muscle structure.

Several other factors can also affect the activity of the MyoD family (Muscat et al. 1995 ), including protein kinase $C$, fibroblast growth factor (FGF), transforming growth factor- $\beta$ (TGF- $\beta$ ) and oncogene products such as $c-f o s$ and $c-j u n$ that promote cell division (Fig. 1). Furthermore, the MyoD proteins act in concert with a variety of other ubiquitous (e.g. Spl, CAAT box-binding transcription factor (CTF), serum response factor (SRF)) and tissue-specific (e.g. MEF2) transcription factors to regulate myogenic promoters.

Prenatal development. Embryonic pre-myogenic cells are probably converted into myoblasts by the expression of MyoD or Myf-5, and the appearance of these factors activates a gene array that defines myoblast identity at a determined level of commitment (Fig. 1). There is probably a degree of functional redundancy between these two factors because mice bearing targeted null mutations in either MyoD or Myf-5 are able to form muscle and only when both factors are deleted are the young no longer viable (Rudnicki et al. 1993). In addition, MyoD and Myf-5 may also have roles later in development as differentiation factors. By contrast, myogenin and MRF4 are activated after MyoD and Myf-5 and are crucial for terminal differentiation.

The observation that $\mathrm{MyoD}$ and Myf-5 are expressed in different subdomains of the dermamyotome suggests that the two compartments give rise to different muscle lineages. Nevertheless, it is not easy to find consistent correlations between the presence of specific members of the MyoD family and specific fibre characteristics prenatally. Thus, in embryonic muscle the relatively high levels of MyoD and myogenin mRNA are not correlated with the pattern of myosin heavy-chain isoform expression (Lyons et al. 1990), and in cultured cell lines that differentially express the MyoD family of proteins, no correlation with specific myosin heavy-chain isoforms is seen (Miller, 1990).

Postnatal development. Much less clearly understood is the extent to which the previously described mechanisms are relevant to the regulation of postnatal muscle development, and whether the MyoD family acts to restrict expression of muscle genes to specific fibre types or to orchestrate fibre-type switching within a given muscle. The major myogenic transcript in postnatal muscle is MRF4; myogenin and MyoD transcripts are also detectable but at low levels (Rhodes \& Konieczny, 1989). Nevertheless, by contrast with embryonic muscle, the MyoD family may have distinct roles in mediating the effects of extrinsic factors on fibre type-specific gene expression in mature, innervated muscle (Hughes et al. 1993). In adult rats it was found that MyoD and myogenin mRNA were preferentially expressed in fast glycolytic and slow oxidative myofibres respectively, and manipulation of hormone levels or innervation resulted in alterations in MyoD and myogenin expression that paralleled changes in fibre type. These results suggest that the MyoD family regulates both the early development of muscle and its ability to adapt to changing environments in postnatal life and that the mechanisms in each case might be quite distinct. 
Consistent with a role for the MyoD family in postnatal muscle regulation in addition to early muscle differentiation is the presence of a myogenic enhancer factor 1 (MEF1) site in the mouse adult IIB myosin heavy-chain promoter which is capable of binding MyoD (Takeda et al. 1992). In addition to the DNA sequence specificity within the individual gene promoters and enhancers per se there is clearly a complex interplay of bHLH and accessory transcription factors capable of generating a wide spectrum of subtle regulatory signals which could modulate fibre type in response to postnatal environment.

\section{Thyroid hormones (TH)}

Mechanisms of action. TH play a central role in development and homeostasis and are the most well-studied hormones with respect to muscle development. For example, they stimulate conversion of slow to fast myosin heavy-chain isoforms (d'Albis \& ButlerBrowne, 1993), increase the abundance of mitochondria and their respiratory enzymes (Brand \& Murphy, 1987), and increase the concentrations of $\mathrm{Na}^{+}, \mathrm{K}^{+}$-ATPase $(E C$ 3.6.1.37) and $\mathrm{Ca}^{2+}$-ATPase (EC 3.6.1.38; Clausen et al. 1991). Moreover, they play a key role in myogenesis and differentiation (Fig. 1) and the current hypothesis on hormonal regulation of myogenesis is that $\mathrm{TH}$ directly regulate both the MyoD family of transcription factors and contractile protein genes themselves, and induce TH receptortranscription factor interactions which are critical to gene expression (Izumo et al. 1986; Carnac et al. 1992; Muscat et al. 1995). Changes in TH can thus lead to profound alterations in gene and isoform expression, morphology, and biochemical and contractile properties of muscle.

The actions of $\mathrm{TH}$ are mediated by the interaction of a ligand-activated receptor with specific DNA sequences, termed TH response elements, usually located in the $5^{\prime}$ promoter region of target genes. The nuclear receptors for TH occur as a series of isoforms and are encoded by two distinct genes, c-erbA $\alpha$ and c-erb $A \beta$ (Lazar, 1993), and evidence from developing rat muscle suggests that these isoforms may be differentially expressed in a muscle-specific and developmental stage-specific fashion (Hoffman et al. 1994). TH receptors normally need to form heterodimers with an accessory factor to achieve high-affinity binding, and the retinoid $\mathrm{X}$ receptor, which is activated specifically by 9 -cis retinoic acid, is one such group of proteins (Kliewer et al. 1992).

The regulatory mechanisms by which $\mathrm{TH}$, in conjunction with their receptors and those for 9-cis retinoic acid, regulate muscle development display intriguing subtleties. For example, retinoid $\mathrm{X}$ receptors exist as different isoforms that are expressed at different levels in skeletal muscle (Mangelsdorf et al. 1992) and show differential responses to $\mathrm{TH}$ (Mano et al. 1994); and although all TH response elements interact efficiently with $\mathrm{TH}$-retinoid $\mathrm{X}$ receptor complexes, specific $\mathrm{TH}$ response element sequences display distinct heterodimer isoform preferences. However, it is not possible at this stage to provide a molecular explanation of fibre type-specific switching in postnatal muscle in terms of the actions of different heterodimer configurations on specific gene targets. Much work still needs to be done in defining the distribution of the TH and retinoid receptor isoforms in specific skeletal muscles, in determining their sensitivities to nutritional and hormonal change and in demonstrating the molecular basis for a hierarchy of regulatory responses.

Developmental changes in thyroid hormones. The relative importance of $\mathrm{TH}$ in early 



Fig. 2. Developmental profiles of (a) plasma thyroxine $\left(T_{4}\right)$ and (b) 3,5,3'-triiodothyronine $\left(T_{3}\right)$ concentrations, and (c) skeletal-muscle nuclear thyroid hormone (TH) receptors, during the last 5 weeks of gestation in the pig. ND, not detected; i.e. below detection limit of the assay. Maximal $\mathrm{T}_{3}$-binding capacity ( $\mathrm{B}_{\max }$ ) was assessed in nuclear extracts of muscle with known DNA content. (From Duchamp et al. 1994a.)

embryonic and fetal development of muscle compared with postnatal life has yet to be established. Although TH receptors cannot be detected in the liver until shortly before birth, the maximal 3,5,3'-triiodothyronine $\left(\mathrm{T}_{3}\right)$-binding capacity of porcine skeletal muscle nuclei is already high at $80 \mathrm{~d}$ of gestation and then shows a further increase around birth at $114 \mathrm{~d}$ (Fig. 2; Duchamp et al. 1994a). Early in gestation, however, $\mathrm{T}_{3}$ is undetectable in the plasma. Nevertheless, circulating thyroxine $\left(\mathrm{T}_{4}\right)$ is present in the fetus (Fig. 2) and it may also be converted to $T_{3}$ in the target tissues, suggesting a key role for $\mathrm{T}_{4}$ in early prenatal development of muscle. Alternatively, during prenatal development, unliganded $\mathrm{TH}$ receptors may function directly as activators or repressors of muscle differentiation, as described previously in cultured cells (Lazar, 1993).

Perinatal development in mammals is associated with marked changes in circulating concentrations of $\mathrm{TH}$, the precise pattern of which is dependent on stage of maturity at birth. Thus, $T_{3}$ is barely detectable in embryonic and newborn rats, increases a few days after birth, reaches a peak at 2 weeks, and then declines to a plateau in the adult (Dubois $\&$ Dussault, 1977). In a more mature species, the pig, $T_{3}$ is virtually undetectable in the plasma at $80 \mathrm{~d}$ of gestation, it is present at low levels during the last week of gestation, shows a dramatic surge during the first $6 \mathrm{~h}$ after birth, remains elevated over the next $2 \mathrm{~d}$ and then declines slightly over the next 2 weeks (Berthon et al. 1993). Moreover, porcine hepatic 5'-deiodinase activity also increases markedly between 80 and $110 \mathrm{~d}$ gestation and declines gradually thereafter (Berthon et al. 1993). The probability is that these changes in $\mathrm{TH}$ status have a central role in regulating muscle development in the perinatal period and that the rate of development is coincident with stage of maturity at birth. Thus, coincident with the perinatal increase in plasma $T_{3}$, embryonic and perinatal myosin heavy-chain isoforms are repressed and adult fast myosin heavy-chain isoforms are accumulated (d'Albis \& Butler-Browne, 1993). Furthermore, these perinatal changes in thyroid status may account in part for the marked changes in mitochondrial respiration and biogenesis (Herpin et al. 1996) and striking up-regulation of cation pumps (Harrison et al. 1994) which occur during early postnatal life. 
Postnatally, it is well-established that TH play a central role in controlling the switching between mature myosin heavy-chain isoforms, with hyperthyroidism inducing a transition from slow to fast isoforms, and hypothyroidism inducing an increase in proportion of slow fibres. Moreover, differences between muscles have been observed also in response to changes in $\mathrm{TH}$ postnatally (d'Albis et al. 1990) and the possibility is that these could be related to muscle-specific differences in either the total number of TH receptors or to their specific isoforms (Lazar, 1993). Nevertheless, the precise role of TH postnatally has yet to be clarified because in many studies on the role of thyroid status in muscle development animals are fed ad lib., even though changes in thyroid status alter voluntary food intake and metabolic rate (Dauncey, 1990), both of which can themselves influence muscle development. In a study on the effects of a short period of mild hypothyroidism under conditions of controlled energy intake on muscle development in the neonatal pig, it was found that a $50 \%$ decrease in circulating $\mathrm{TH}$ concentrations induced only a very slight increase in the proportion of slow fibres (Harrison et al. 1993). Moreover, there was an up-regulation in nuclear TH receptor numbers, which contrasted strikingly with the effect of undernutrition on TH status; not only are plasma TH levels reduced but there is also a reduction in $\mathrm{TH}$ receptor numbers in individuals on a restricted energy intake (Dauncey, 1990). This suggests that the precise role of TH in muscle development postnatally needs to be re-assessed under conditions of controlled food intake.

The previously mentioned observations suggest that, as with the MyoD family of proteins, there may be distinct differences in the role of $\mathrm{TH}$ at different stages of development. During early development TH are involved in exit of myoblasts from the cell cycle and into the quiescent state of $\mathrm{G}_{0}$, whereas later in development they are involved primarily in determining the functional characteristics of muscle by switching of mature muscle-specific genes. Whether they are also involved in the postnatal differentiation of tertiary myoblasts in large mammals remains to be established.

\section{Other hormones and growth factors}

Glucocorticoids, insulin and growth hormone $(G H)$. In addition to the central role played by $\mathrm{TH}$, other hormones such as glucocorticoids, insulin and GH may also be involved, although their precise roles remain to be elucidated. It has been shown that myosin heavy-chain isoforms can be affected postnatally by each of these hormones. Thus, cortisone treatment of adult rats induces selective atrophy of specific fibre types and a change in fibre type distribution in a muscle-specific fashion (Polla et al. 1994), while insulin also appears to exert a muscle-specific action on myosin heavy-chain isoforms (Rutschmann et al. 1984). Moreover, an increase in GH activity may induce an increase in the proportion of slow- compared with fast-twitch fibres (Ayling et al. 1992).

The glucocorticoids have a unique function in preparing the fetus for postnatal life (Liggins, 1994). There is a marked perinatal surge in plasma cortisol, the precise timing of which varies between species, and this hormone acts both independently and synergistically with other hormones such as $\mathrm{TH}$ in the development of many tissues including the lungs, liver and gastrointestinal tract. However, the precise role of this increase in cortisol on muscle development has received little attention, although the possibility is that both myofibre differentiation and cation pump concentrations may be affected. 
Although plasma levels of $\mathrm{GH}$ are very high in the fetus and decline to reach low values at birth (Bassett et al. 1970), experimental data on fetal growth combined with the low abundance of hepatic $\mathrm{GH}$ receptor had suggested that plasma $\mathrm{GH}$ at this age was not functionally significant. More recently, however, presence of either the GH receptor or GH-binding protein has been demonstrated in the rat embryo and fetus with maximum expression occurring during organogenesis (García-Aragón et al. 1992). Moreover, the prenatal ontogeny of $\mathrm{GH}$ receptor gene expression in muscle is markedly different from that in liver; levels of GH receptor mRNA in porcine muscle are already high at 5 weeks before birth (Duchamp et al. 1994b). The probability is therefore that the high levels of plasma $\mathrm{GH}$ coupled with high abundance of $\mathrm{GH}$ receptors are important in muscle development during fetal life.

Not only do interactions occur between, for example, $\mathrm{TH}$ and the MyoD family of regulatory proteins, but they also occur between the different hormone systems. Thus, there is a marked tissue-specific effect of prenatal thyroid status on expression of the GH receptor gene (Duchamp et al. 1994b). In this study, mild hypothyroidism in the fetal pig during late gestation induced down-regulation of hepatic $\mathrm{GH}$ receptor, whereas abundance of the receptor in muscle increased by approximately $70 \%$. In view of the marked changes in hormones and their receptors during development, the precise interactions between these variables should be addressed in future studies.

Insulin-like growth factors (IGF), other growth factors and oncogene products. IGF and their type 1 receptor play a critical role not only in the early stages of myogenesis at the level of stem cell proliferation, but also in terminal differentiation of myoblasts into myotubes (Florini \& Ewton, 1992; Kou \& Rotwein, 1993). Much of this work has been carried out in cultured cell lines which may possess an unusual pattern of expression of the MyoD family of regulatory proteins, for example the L6 rat myoblast does not express the $M y_{o} D$ gene (Florini et al. 1991). However, as described earlier, MyoD and Myf-5 precede other members of the MyoD family in the regulatory hierarchy (Fig. 1) and it is likely that in L6 cells the absence of MyoD is compensated for by redundancy in the actions of other members of the family.

Transfection of cultured myoblasts from a variety of sources with MyoD and also direct in situ hybridization analysis of developing muscle has suggested that an early step in the induction of differentiation is the activation of the myogenin gene by MyoD; in the case of the L6 cell, addition of IGF-I to the culture medium fulfils this requirement. Given the somewhat atypical profile of the L6 cell with respect to the MyoD family it seems reasonable to ask whether IGF is a general requirement for this step in muscle differentiation. Some support for this comes from analysis of IGF expression in skeletal muscle of the fetus during gestation. The levels of IGF-I and IGF-II mRNA in fetal tissues are uniformly low throughout gestation, except in muscle at the time when secondary fibre formation is known to be taking place (Fig. 3). Although no specific function has yet been attached to this increase in IGF mRNA, these high levels of IGF expressed in muscle may play a key role in prenatal muscle development. Furthermore, they may be particularly susceptible to changes in fetal nutrition. Postnatally, IGF almost certainly play a role in fibre hypertrophy (Devol et al. 1990), but whether they are also involved in production of tertiary myotubes in large mammals remains to be determined. These possibilities are discussed in a later section (p. 555).

By contrast with the role of IGF in stimulating differentiation, other growth factors such as FGF and TGF- $\beta$ are potent inhibitors (Fig. 1), although, as mentioned earlier, 

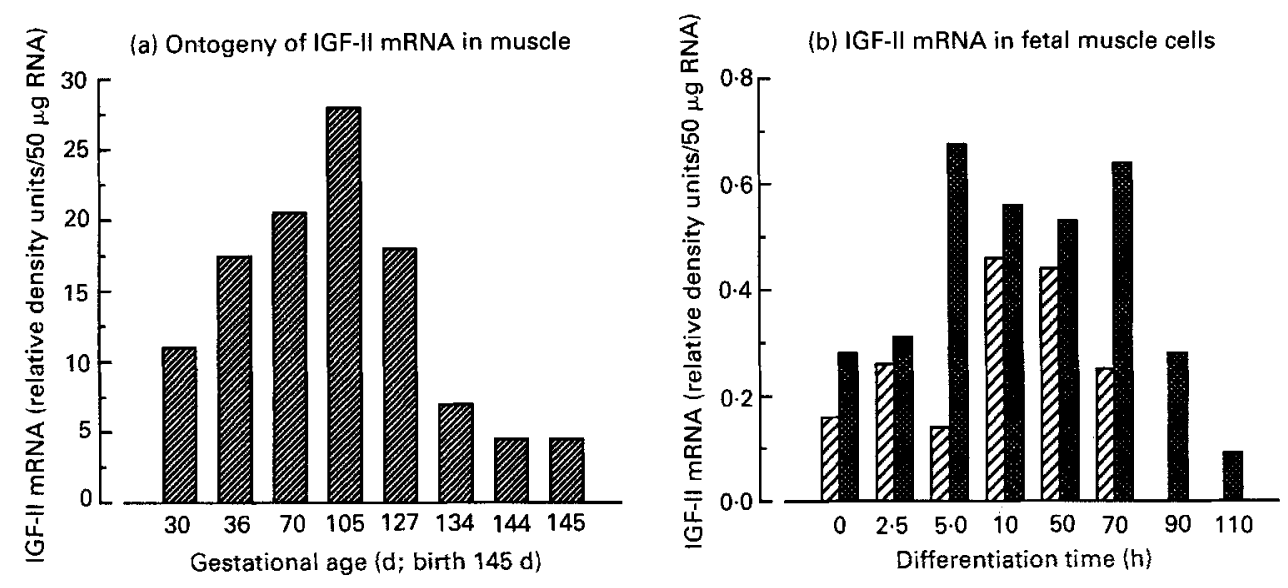

Fig. 3. (a) Levels of insulin-like growth factor (IGF)-II mRNA in skeletal muscle RNA from fetal sheep at different stages of gestation, measured by RNase protection assay using a probe for the first coding exon of ovine IGF-II (Li et al. 1993). Levels at 3 weeks and 5 months postnatally were approximately two density units. (b) Levels of IGF-II mRNA during differentiation of primary muscle cells isolated from 7-(2D) and 12-week-old (D) sheep fetuses. Measurements were made on whole-cell RNA, as described previously. (From J. Cripps, P. Speck and R. S. Gilmour, unpublished results.)

they also appear to act by altering gene expression of the $\mathrm{MyoD}$ family of regulatory proteins.

In addition to the role of oncogene products such as c-fos and c-jun in inhibiting differentiation of myoblasts (Fig. 1), evidence suggests that the early response genes c-ski and egr 1 are involved in regulating skeletal muscle development. In both mice and cattle transgenic for c-ski there is extensive muscle hypertrophy and non-significant effects on other organs, and these effects appear to be restricted to certain fibre types (Sutrave et al. 1990; Bowen et al. 1994). Furthermore, the egr1 gene encodes a highly conserved zinc-finger transcription factor (Drummond et al. 1994) and may play a role in muscle hypertrophy (Iwaki et al. 1990).

\section{MODULATION BY NUTRITION AND ENVIRONMENT}

\section{Prenatal development}

Muscle fibre number is a critical determinant of muscle mass and there is considerable evidence which indicates that the number of primary fibres is a relatively more fixed genetic component than that of secondary fibres (Handel \& Stickland, 1987; Wilson et al. 1988; Dwyer \& Stickland, 1991). Thus, maternal undernutrition or growth retardation in utero have little effect on primary numbers whereas the formation of secondary myotubes is reduced, resulting in a permanent deficit in total fibre numbers. Moreover, nutritional restriction of pregnant guinea-pigs during the first third of gestation produces the same deficit of approximately $20-28 \%$ in muscle fibre number in the neonates as does restriction throughout pregnancy (Dwyer et al. 1996). It appears, therefore, that inadequate nutrition at critical periods in early gestation can have profound effects on muscle fibre development later in gestation. 
Furthermore, a high maternal feed intake or administration of porcine somatotropin to pregnant sows at specific periods in early gestation induces the formation of significantly more fibres in fetal semitendinosus muscle and increases average secondary: primary fibre number in the fetus and neonate (Rehfeldt et al. 1993; Dwyer et al. 1994). The possibility is that these manipulations in early pregnancy have a permanent effect on the development of the placenta, thereby affecting fetal IGF levels with consequent effects on the developing muscle (Dwyer \& Stickland, 1992).

\section{Postnatal development}

After birth it becomes increasingly difficult to separate the effects of intrinsic changes in hormone status from those induced by extrinsic factors such as nutrition and thermal environment. Both these external variables change significantly after birth and they can in turn markedly influence the hormonal and growth factor status of all mammals (Dauncey, 1995a,b; Symonds et al. 1995). Thus, food intake alters not only the circulating concentrations of TH, cortisol, GH and IGF-I but also the receptors for these hormones. Moreover, changes are not necessarily related simply to level of energy intake but to energy supply in relation to demand. For example, $\mathrm{GH}$ receptor gene expression is elevated in muscle because of either a low energy intake or a high thermoregulatory demand (Dauncey et al. 1994b; Weller et al. 1994). By contrast, however, plasma TH levels remain elevated in a cold environment only if energy intake is elevated to sustain the increased metabolic demand (Dauncey, 1990).

Of particular interest in the present context is the extent to which myogenesis and differentiation may be altered postnatally, and recent evidence from studies with large mammals suggests that both these variables can be altered by either energy status, i.e. the balance between energy intake and energy expenditure, or growth factors in maternal milk.

Energy status. Perinatal undernutrition has a marked influence on the maturation of myosin heavy-chain isoforms. In undernourished rats, histochemical differentiation is retarded at birth, with all myofibres or myotubes being of the fetal type (Haltia et al. 1978). Moreover, the normal postnatal decrease in the neonatal myosin heavy-chain isoform is delayed, and the possibility is that this delayed switching is induced by the hypothyroidism associated with undernutrition (Brozanski et al. 1991).

In relation to the pathophysiology of starvation, undernutrition and overnutrition, skeletal muscle may account for a large proportion of the total energy expenditure and is, therefore, of particular interest with respect to possible mechanisms for altering the energy utilization of resting and contracting muscles (Waterlow, 1990). A major effect of undernutrition is a reduction in fibre size (Stickland et al. 1975). Moreover, studies in adult humans indicate that a period of energy deficiency results in selective preservation of fibre size, with the size of type I slow fibres being maintained while type II fast fibres are reduced in size (Schantz et al. 1983), and food restriction in the rat also tends to affect fast fibre size selectively (Polla et al. 1994). The possibility is that these changes act to conserve energy under conditions where supplies are restricted. In young growing animals, by contrast, there are no fibre-specific changes in cell size and under conditions of energy restriction all fibres are smaller, indicating that the mechanisms for hypertrophic growth compared with those for maintaining cell size are different (Haltia et al. 1978; Harrison et al. 1996). 

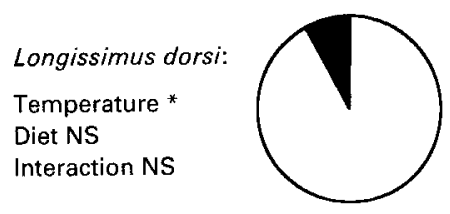

$26^{\circ}$ High
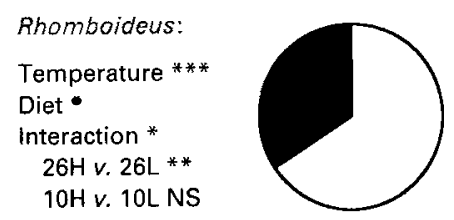

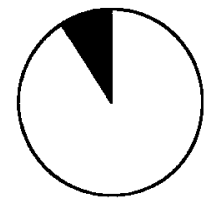

$26^{\circ}$ Low

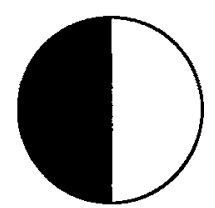

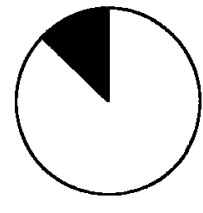

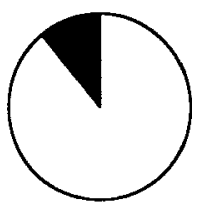

$10^{\circ} \mathrm{High}$
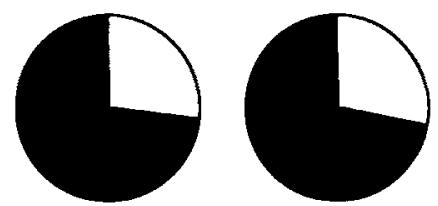

Fig. 4. Muscle-specific regulation of differentiation between mature myofibre types by energy status. Proportions of type I slow ( $\boldsymbol{\square}$ ) and type II fast $(\square)$ myofibres were assessed by enzyme cytochemistry in longissimus dorsi and rhomboideus muscles from 7-week-old pigs which had been living for 1 month at a thermally neutral $\left(26^{\circ}\right)$ or cool $\left(10^{\circ}\right)$ environmental temperature on a high $(\mathrm{H})$ or low $(\mathrm{L})$ energy intake $(\mathrm{H}=$ 2L). Results from analysis of variance: ${ }^{*} P<0 \cdot 05,{ }^{* *} P<0 \cdot 01,{ }^{* * *} P<0 \cdot 001$, NS, not significant. (From Harrison et al. 1996.)

There are, however, marked muscle-specific effects of energy status on fibre type distribution in young animals (Harrison et al. 1996): a low energy intake and a high thermoregulatory demand both result in a marked increase in the proportion of type I fibres in rhomboideus but not soleus or longissimus dorsi muscles of young pigs (Fig. 4). Changes occur not only in fibre types as assessed by myosin ATPase (EC 3.6.1.32) cytochemistry but also in the abundance of myosin heavy-chain isoform proteins. Moreover, control is exerted at the level of gene expression because there is also a striking increase in slow myosin heavy-chain mRNA expression in rhomboideus of young animals on a low energy intake compared with a high energy intake (White et al. 1995). The energy expenditure per unit tension developed is lower in slow fibres than in fast fibres and, therefore, these postnatal changes in differentiation between mature myosin heavy-chain isoforms of rhomboideus muscle will improve the energetic efficiency of contraction on a reduced food intake and also enhance its ability to act as a thermogenic organ (Herpin \& Barré, 1989). Transition from fast to slow myosin heavy-chain isoforms can be induced by a reduction in thyroid status (d'Albis \& Butler-Browne, 1993) and increased contractile activity (Goldspink et al. 1992). The possibility is that the changes in myosin heavy-chain isoforms induced by nutrition are related to concomitant changes in thyroid status, while those due to temperature are also related to the marked increase in contractile activity due to shivering. In view of the studies described earlier in this review on the role of the MyoD family postnatally (Hughes et al. 1993) it can be hypothesized that these actions may in turn be regulated specifically by MyoD and myogenin (M. J. Dauncey and A. M. Rowlerson, unpublished results).

Insulin-like growth factors. The extent to which growth factors can modify muscle development postnatally is not known. However, the high levels of growth factors in colostrum and maternal milk (Donovan \& Odle, 1994) affect intestinal development and they may also modify myofibre hypertrophy and hyperplasia during this period. Moreover, level of energy intake has a marked influence on circulating IGF-I and 
IGF-binding proteins and this may itself influence normal muscle development postnatally (Dauncey et al. 1994c). However, the IGF-I mRNA content of muscle in pigs aged 2 months is reduced only when growth rate is markedly restricted (Weller et al. 1994), suggesting that during undernutrition there is impairment of the paracrine, autocrine and endocrine functions of IGF-I.

Recent studies in the neonatal pig suggest that nutrition at this age may be critical to muscle development. During the first 2 weeks after birth, piglets left with the sow grow much more rapidly than those fed on a sow's-milk-replacement formula and this may be due to either the composition or the quantity of milk consumed (Dauncey et al. 1994a). Replacement formula does not contain growth factors and in a comparison between maternal-fed and formula-fed animals, our preliminary results indicate that tertiary fibres are observed only in maternal-fed animals (A. P. Harrison, A. M. Rowlerson and M. J. Dauncey, unpublished results). There is clearly a need for detailed studies on the roles of both the quantity and composition of milk in postnatal development of muscle.

\section{FUTURE PERSPECTIVES}

The present short review has focused specifically on muscle development in relation to myogenesis, differentiation and transitions between myosin heavy-chain isoforms. In relation to nutritional and environmental modulation of development, the roles of energy status and growth factors have been highlighted. The sarcolemmal $\mathrm{Na}^{+}, \mathrm{K}^{+}$ATPase and sarcoplasmic reticulum $\mathrm{Ca}^{2+}$-ATPase are also known to be subject to regulation by extrinsic factors (Dauncey \& Harrison, 1996). Clearly there are many other aspects of muscle development, such as glucose handling and insulin sensitivity, which could be critically affected by nutritional and environmental factors in embryonic, fetal and postnatal life.

It is highly probable that deficits in many specific nutrients including proteins and vitamins will also influence muscle development. In view of the central role of $\mathrm{TH}$ in muscle development, nutrient-gene interactions with respect to $\mathrm{TH}$ assume particular significance. To take just three examples: first, in protein deficiency, interactions between $\mathrm{T}_{3}$ and insulin could exert a profound regulatory influence on protein metabolism in muscle, influencing the pattern of gene expression as well as overall rates of protein synthesis and turnover (Millward et al. 1989). Second, the outcome of specific vitamin deficiencies needs to be investigated because vitamins $A$ and D interact with TH at several points in their metabolism and there is close homology and heterodimerization between the receptors for these three groups of ligands (Schräder et al. 1994). Third, the discovery that type I iodothyronine $5^{\prime}$-deiodinase $(E C$ 3.8.1.4) is a Se-containing enzyme (Arthur et al. 1990) suggests a role for this micronutrient in muscle development via its effects on $\mathrm{TH}$, as distinct from the well-described effects of Se in preventing accumulation of toxic peroxides on the muscle cell membrane. Moreover, the response to a specific nutrient deficit is likely to be modified by iodine status because iodine is an essential component of TH. These interactions between $\mathrm{TH}$ and specific nutrients have important implications in relation to development of appropriate muscle function in infants and, hence, to public-health nutrient-supplementation programmes.

The previously described examples indicate the considerable impact which specific nutrient deficiencies could have on muscle development. In view of the strong possibility that fetal and early infant nutrition have long-term influences on growth, health and the 
incidence of disease (Barker et al. 1993; Morley \& Lucas, 1994), it also becomes particularly important to determine whether any adverse effects of impaired early nutrition on muscle development can be reversed or ameliorated by subsequent optimization of nutrition. Increased knowledge of the mechanisms by which early environment affects muscle development will have significant implications for the acquisition of appropriate muscle function in all young mammals and may also have long-term consequences in the field of preventative medicine.

\section{REFERENCES}

Arthur, J. R., Nicol, F. \& Beckett, G. J. (1990). Hepatic iodothyronine 5'-deiodinase. The role of selenium. Biochemical Journal 272, 537-540.

Ayling, C. M., Zanelli, J. M., Moreland, B. M. \& Schulster, D. (1992). Effect of human growth hormone injection on the fibre type composition and metabolic activity in a skeletal muscle from normal and hypophysectomized rats. Growth Regulation 2, 133-143.

Barker, D. J. P., Gluckman, P. D., Godfrey, K. M., Harding, J. E., Owens, J. A. \& Robinson, J. S. (1993). Fetal nutrition and cardiovascular disease in adult life. Lancet 341, 938-941.

Bassett, J. M., Thorburn, G. D. \& Wallace, A. L. C. (1970). The plasma growth hormone concentration in the fetal lamb. Journal of Endocrinology 48, 251-263.

Benezra, R., Davis, R. L., Lockson, D., Turner, D. L. \& Weintraub, H. (1990). The protein Id: a negative regulator of helix-loop-helix DNA binding proteins. Cell 61, 49-59.

Berthon, D., Herpin, P., Duchamp, C., Dauncey, M. J. \& Le Dividich, J. (1993). Modification of thermogenic capacity in neonatal pigs by changes in thyroid status during late gestation. Journal of Developmental Physiology 19, 253-261.

Brand, M. D. \& Murphy, M. P. (1987). Control of electron flux through the respiratory chain in mitochondria and cells. Biological Reviews 63, 141-193.

Brozanski, B. S., Daood, M. J., LaFramboise, W. A., Watchko, J. F., Foley, T. P., Butler-Browne, G. S., Whalen, R. G., Guthrie, R. D. \& Ontell, M. (1991). Effects of perinatal undernutrition on elimination of immature myosin isoforms in the rat diaphragm. American Journal of Physiology 261, L49-L54.

Bowen, R. A., Reed, M. L., Schnieke, A., Seidel, G. E., Stacey, A., Thomas, W. K. \& Kajikawa, O. (1994). Transgenic cattle resulting from biopsied embryos: expression of c-ski in a transgenic calf. Biology of Reproduction 50, 664-668.

Buckingham, M. (1994). Molecular biology of muscle development. Cell 78, 15-21.

Carnac, G., Albagli-Curiel, O., Vandromme, M., Pinset, C., Montarras, D., Laudet, V. \& Bonnieu, A. (1992). 3,5,3'-Triiodothyronine positively regulates both MyoD1 gene transcription and terminal differentiation in C2 myoblasts. Molecular Endocrinology 6, 1185-1194.

Chang, K. C., Fernandes, K. \& Dauncey,"M. J. (1995). Molecular characterization of a developmentally regulated porcine skeletal myosin heavy chain gene and its $5^{\prime}$ regulatory region. Journal of Cell Science 108, 1779-1789.

Clausen, T., van Hardeveld, C. \& Everts, M. E. (1991). Significance of cation transport in control of energy metabolism and thermogenesis. Physiological Reviews 71, 733-774.

d'Albis, A. \& Butler-Browne, G. (1993). The hormonal control of myosin isoform expression in skeletal muscle of mammals: a review. Basic and Applied Myology 3, 7-16.

d'Albis, A., Chanoine, C., Janmot, C., Mira, J. C. \& Couteaux, R. (1990). Muscle-specific response to thyroid hormone of myosin isoform transitions during rat postnatal development. European Journal of Biochemistry 193, 155-161.

Dauncey, M. J. (1990). Thyroid hormones and thermogenesis. Proceedings of the Nutrition Society 49, $203-215$.

Dauncey, M. J. (1995a). From whole body to molecule: an integrated approach to the regulation of metabolism and growth. Thermochimica Acta 250, 305-318.

Dauncey, M. J. (1995b). Role of energy status in postnatal growth and development. In Proceedings of the Fourth International Conference on Veterinary Perinatology, pp. 42-47. Newmarket: R. \& W. Publications Limited.

Dauncey, M. J., Burton, K. A. \& Tivey, D. R. (1994a). Nutritional modulation of insulin-like growth factor-I expression in early postnatal piglets. Pediatric Research 36, 77-84. 
Dauncey, M. J., Burton, K. A., White, P., Harrison, A. P., Gilmour, R. S., Duchamp, C. \& Cattaneo, D. (1994b). Nutritional regulation of growth hormone receptor gene expression. FASEB Journal 8, 81-88.

Dauncey, M. J. \& Harrison, A. P. (1996). Developmental regulation of cation pumps in skeletal and cardiac muscle. Acta Physiologica Scandinavica 156, 313-323.

Dauncey, M. J., Rudd, B. T., White, D. A. \& Shakespear, R. A. (1994c). Regulation of insulin-like growth factor binding proteins in young growing animals by alteration of energy status. Growth Regulation $\mathbf{3}$, $198-207$

DeNardi, C., Ausoni, S., Moretti, P., Gorza, L., Velleca, M., Buckingham, M. \& Schiaffino, S. (1993). Type $2 \mathrm{X}$-myosin heavy chain is coded by a muscle fiber type-specific and developmentally regulated gene. Journal of Cell Biology 123, 823-835.

Devol, D. L., Rotwein, P., Sadow, J. L., Novakofski, J. \& Bechtel, P. J. (1990). Activation of IGF gene expression during work-induced skeletal muscle growth. American Journal of Physiology 259, E89-E95.

Donovan, S. M. \& Odle, J. (1994). Growth factors in milk as mediators of infant development. Annual Review of Nutrition 14, 147-167.

Draeger, A., Weeds, A. G. \& Fitzsimons, R. B. (1987). Primary, secondary and tertiary myotubes in developing skeletal muscle: a new approach to the analysis of human myogenesis. Journal of Neurological Science 81, 19-43.

Drummond, I. A., Rohwernutter, P. \& Sukhatme, V. P. (1994). The zebrafish egr 1 gene encodes a highly conserved, zinc-finger transcriptional regulator. DNA and Cell Biology 13, 1047-1055.

Dubois, J. D. \& Dussault, J. H. (1977). Ontogenesis of thyroid function in the neonatal rat. Thyroxine $\left(\mathrm{T}_{4}\right)$ and triiodothyronine $\left(\mathrm{T}_{3}\right)$ production rates. Endocrinology 101, 435-441.

Duchamp, C., Burton, K. A., Herpin, P. \& Dauncey, M. J. (1994a). Perinatal ontogeny of porcine nuclear thyroid hormone receptors and its modulation by thyroid status. American Journal of Physiology 267, E687-E693

Duchamp, C., Burton, K. A., Herpin, P. \& Dauncey, M. J. (1994b). Differential regulation of growth hormone receptor gene expression by thyroid status in perinatal pigs. Journal of Endocrinology $140, \mathrm{P} 64$.

Dwyer, C. M., Madgwick, A. J. A., Ward, S. S. \& Stickland, N. C. (1996). The effect of maternal undernutrition in early gestation on the development of fetal myofibres in the guinea pig. Reproduction, Fertility and Development (In the Press).

Dwyer, C. M. \& Stickland, N. C. (1991). Sources of variation in myofibre number within and between litters of pigs. Animal Production 52, 527-533.

Dwyer, C. M. \& Stickland, N. C. (1992). The effects of maternal undernutrition on maternal and fetal serum insulin-like growth factors, thyroid-hormones and cortisol in the guinea-pig. Journal of Developmental Physiology 18, 303-313.

Dwyer, C. M., Stickland, N. C. \& Fletcher, J. M. (1994). The influence of maternal nutrition on muscle-fiber number development in the porcine fetus and on subsequent postnatal-growth. Journal of Animal Science 72, 911-917.

Florini, J. R. \& Ewton, D. Z. (1992). Induction of gene expression in muscle by the IGFs. Growth Regulation 2, 23-29.

Florini, J. R., Ewton, D. Z. \& Roof, S. L. (1991). Insulin-like growth factor-I stimulates terminal myogenic differentiation by induction of myogenin gene expression. Molecular Endocrinology 5, 718-724.

García-Aragón, J., Lobie, P. E., Muscat, G. E. O., Gobius, K. S., Norstedt, G. \& Waters, M. J. (1992). Prenatal expression of the growth hormone $(\mathrm{GH})$ receptor/binding protein in the rat: a role for $\mathrm{GH}$ in embryonic and fetal development? Development 114, 869-876.

Goldspink, G., Scutt, A., Loughna, P. T., Wells, D. J., Jaenicke, T. \& Gerlach, G. F. (1992). Gene expression in skeletal muscle in response to stretch and force generation. American Journal of Physiology 262, R356-R363.

Gundersen, K. \& Merlie, J. P. (1994). Id-1 as a possible transcriptional mediator of muscle disuse atrophy. Proceedings of the National Academy of Sciences, USA 91, 3647-3651.

Gunning, P. \& Hardeman, E. (1991). Multiple mechanisms regulate muscle fiber diversity. FASEB Journal 5 , 3064-3070.

Haltia, M., Berlin, Ö., Schucht, H. \& Sourander, P. (1978). Postnatal differentiation and growth of skeletal muscle fibres in normal and undernourished rats. Journal of the Neurological Sciences 36, 25-39.

Handel, S. E. \& Stickland, N. C. (1987). The growth and differentiation of porcine skeletal muscle fibre types and the influence of birthweight. Journal of Anatomy 152, 107-119.

Harrison, A. P., Clausen, T. \& Dauncey, M. J. (1994). Cation pumps in skeletal muscle undergo dramatic up-regulation in the perinatal period. Proceedings of the Nutrition Society 53, 246A. 
Harrison, A. P., Rowlerson, A. M. \& Dauncey, M. J. (1996). Selective regulation of myofiber differentiation by energy status during postnatal development. American Journal of Physiology (In the Press).

Harrison, A. P., Tivey, D. R., Duchamp, C. \& Dauncey, M. J. (1993). Neonatal hypothyroidism and its influence on contractile and metabolic properties of skeletal muscle. Journal of Endocrinology 139, P49.

Herpin, P. \& Barré, H. (1989). Loose-coupled subsarcolemmal mitochondria from muscle rhomboideus in cold-acclimated piglets. Comparative Biochemistry and Physiology 92B, 59-65.

Herpin, P., Berthon, D., Duchamp, C., Dauncey, M. J. \& Le Dividich, J. (1996). Effect of thyroid status in the perinatal period on oxidative capacities and mitochondrial respiration in porcine liver and skeletal muscle. Reproduction, Fertility and Development (In the Press).

Hoffman, R. K., Lazar, M. A., Rubinstein, N. A. \& Kelly, A. M. (1994). Differential expression of $\alpha 1, \alpha 2$, and $\beta 1$ thyroid hormone receptor genes in developing rat skeletal muscle. Journal of Cell Biochemistry 18D, 517.

Hughes, S. M., Taylor, J. M., Tapscott, S. J., Gurley, C. M., Carter, W. J. \& Peterson, C. A. (1993). Selective accumulation of MyoD and Myogenin mRNAs in fast and slow adult skeletal muscle is controlled by innervation and hormones. Development 118, 1137-1147.

Iwaki, K., Sukhatme, V. P., Shubeita, H. E. \& Chien, K. R. (1990). $\alpha$ - and $\beta$-Adrenergic stimulation induces distinct patterns of immediate early gene expression in neonatal rat myocardial cells. Journal of Biological Chemistry 265, 13809-13817.

Izumo, S., Nadal-Ginard, B. \& Mahdavi, V. (1986). All members of the MHC multigene family respond to thyroid hormone in a highly tissue-specific manner. Science 231, 597-600.

Kliewer, S. A., Umesono, K., Mangelsdorf, D. J. \& Evans, R. M. (1992). Retinoid X receptor interacts with nuclear receptors in retinoic acid, thyroid hormone and vitamin $\mathrm{D}_{3}$ signalling. Nature $\mathbf{3 5 5}, 446-449$.

Kou, K. \& Rotwein, P. (1993). Transcriptional activation of the insulin-like growth factor-II gene during myoblast differentiation. Molecular Endocrinology 7, 291-302.

Lazar. M. A. (1993). Thyroid hormone receptors. Multiple forms, multiple possibilitics. Endocrine Reviews 14, 184-193.

Li, J., Saunders, J. C., Gilmour, R. S., Silver, M. \& Fowden, A. L. (1993). Insulin-like growth factor-II messenger ribonucleic acid expression in fetal tissues of the sheep during late gestation: effects of cortisol. Endocrinology 132, 2083-2089.

Liggins, G. C. (1994). The role of cortisol in preparing the fetus for birth. Reproduction, Fertility and Development 6, 141-150.

Lyons, G. E., Ontell, M., Cox, R., Sassoon, D. \& Buckingham, M. (1990). The expression of myosin genes in developing skeletal muscle in the mouse embryo. Journal of Cell Biology 111, 1465-1476.

Mangelsdorf, D. J., Borgmeyer, U., Heyman, R. A., Yang Zhou, J., Ong, S., Oro, A. E., Kakzuka, A. \& Evans, R. M. (1992). Characterization of three RXR genes that mediate the action of 9-cis retinoic acid. Genes and Developmem 6, 329-344.

Mano, H., Mori, R., Ozawa, T., Takeyama, K., Yoshizawa, Y., Kojima, R., Arao, Y., Masushige, S. \& Kato, $S$. (1994). Positive and negative regulation of retinoid $X$ receptor gene expression by thyroid hormone in the rat. Journal of Biological Chemistry 269, 1591-1594.

Mascarello. F.. Stecchini, M. L., Rowlerson, A. \& Ballocchi, E. (1992). Tertiary myotubes in postnatal growing pig muscle detected by their myosin isoform composition. Journal of Animal Science $\mathbf{7 0 ,}$ 1806-1813.

Miller, J. B. (1990). Myogenic programs of mouse muscle cell lines: expression of myosin heavy chain isoforms, MyoD1, and Myogenin. Journal of Cell Biology 111, 1149-1159.

Millward, D. J., Jackson, A. A.. Price, G. \& Rivers, J. P. W. (1989). Human amino acid and protein requirements: current dilemmas and uncertainties. Nutrition Research Reviews 2, 109-132.

Morley, R. \& Lucas, A. (1994). Influence of early diet on outcome in preterm infants. Acta Paediatrica 83 , 123-126.

Muscat. G. E. O., Downes, M. \& Dowhan, D. H. (1995). Regulation of vertebrate muscle differentiation by thyroid hormone: the role of the myoD gene family. BioEssays 17, 211-218.

Novakofski, J. \& McCusker, R. H. (1993). Physiology and principles of muscle growth. In Growth of the Pig, pp. 33-48 [G. R. Hollis, editor]. Wallingford: CAB International.

Oison, E. N. (1993). Signal transduction pathways that regulate skeletal muscle gene expression. Molecular Endocrinology 7, 1369-1378.

Pette, D. \& Staron, R. S. (1990). Cellular and molecular diversities of mammalian skeletal muscle fibers. Reviews in Physiology, Biochemistry and Pharmacology 116, 1-76. 
Polla, B., Bottinelli, R., Sandoli, D., Sardi, C. \& Reggiani, C. (1994). Cortisone-induced changes in myosin heavy chain distribution in respiratory and hindlimb muscles. Acta Physiologica Scandinavica 151, 353-361.

Rehfeldt, C., Fiedler, I., Weikard, R., Kanitz, E. \& Ender, K. (1993). It is possible to increase skeletal muscle fibre number in utero. Bioscience Reports 13, 213-220.

Rhodes, S. J. \& Konieczny, S. F. (1989). Identification of MRF4: a new member of the muscle regulatory factor gene family. Genes and Development 3, 2050-2061.

Ross, J. J., Duxson, M. J. \& Harris, A. J. (1987). Neural determination of muscle fibre numbers in embryonic rat lumbrical muscles. Development 100, 395-409.

Rowlerson, A. (1994). An outline of fibre types in vertebrate skeletal muscle: histochemical identification and myosin isoforms. Basic and Applied Myology 4, 333-352.

Rudnicki, M. A., Schnegelsberg, P. N. J., Stead, R. H., Braun, T., Arnold, H.-H. \& Jaenisch, R. (1993). MyoD or Myf-5 is required in a functionally redundant manner for the formation of skeletal muscle. Cell 75, 1351-1359.

Rutschmann, M., Dahlmann, B. \& Reinauer, H. (1984). Loss of fast-twitch isomyosins in skeletal muscles of diabetic rat. Biochemical Journal 221, 645-650.

Schantz, P.. Henriksson, J. \& Jansson, E. (1983). Adaptation of human skeletal muscle to endurance training of long duration. Clinical Physiology 3, 141-151.

Schräder, M., Müller, K. M., Nayeri, S., Kahlen, J.-P. \& Carlberg, C. (1994). Vitamin D 3 -thyroid hormone receptor heterodimer polarity directs ligand sensitivity of transactivation. Nature 370, 382-386.

Stickland, N. C., Widdowson, E. M. \& Goldspink, G. (1975), Effects of severe energy and protein deficiencies on the fibres and nuclei in skeletal muscle of pigs. British Journal of Nutrition 34, 421-428.

Stockdale, F. E. (1992). Myogenic cell lineages. Developmental Biology 154, 284-298.

Symonds, M. E., Bird, J. A., Clarke, L., Gate, J. J. \& Lomax, M. A. (1995). Nutrition, temperature and homeostasis during perinatal development. Experimental Physiology 80, 907-940.

Sutrave, P., Kelly, A. M. \& Hughes, S. H. (1990). ski can cause selective growth of skeletal muscle in transgenic mice. Genes and Development 4, 1462-1472.

Takeda, S., North, D. L., Lakich, M. M., Russell, S. D. \& Whalen, R. G. (1992). A possible regulatory role for conserved promoter motifs in an adult-specific muscle myosin gene from mouse. Journal of Biological Chemistry 267, 16957-16967.

Waterlow, J. C. (1990). Mechanisms of adaptation to low energy intakes. In Diet and Disease in Traditional and Developing Societies, pp. 5-23 [G. A. Harrison and J. C. Waterlow, editors]. Cambridge: Cambridge University Press.

Weller, P. A., Dauncey, M. J., Bates. P. C., Brameld, J. M., Buttery, P. J. \& Gilmour, R. S. (1994). Regulation of porcine insulin-like growth factor I and growth hormone receptor mRNA expression by energy status. American Journal of Physiology 266, E776-E785.

White, P., Chang. K. C. \& Dauncey, M. J. (1995). Role of energy intake in the differential expression of skeletal myosin heavy chain genes during growth. In Skeletal Muscle: Form and Function in Health and Disease, p. 24. London: The Wellcome Trust.

Wilson, S. J., McEwan, J. C., Sheard, P. W. \& Harris, A. J. (1992). Early stages of myogenesis in a large mammal: formation of successive generations of myotubes in sheep tibialis cranialis muscle. Journal of Muscle Research and Cell Motility 13, 534-550.

Wilson, S. J., Ross, J. J. \& Harris, A. J. (1988). A critical period for formation of secondary myotubes defined by prenatal undernourishment in rats. Development 102, 815-821. 